\title{
Cognitive Models for Gastronomic Creation and Innovation
}

\author{
David Casacuberta \\ UNIVERSITAT AUTÒNOMA DE BARCELONA \\ david.casacubertånuab.cat
}

ORCID. 0000-0001-7119-9342

Received: 28/04/2020

Accepted: 01/09/2020

\begin{abstract}
Based on the reflections of super-chef Ferran Adrià and his team at el Bulli restaurant, this paper explores how certain creative mechanisms, techniques and procedures surrounding avant-garde gastronomy can be analysed from an enactivist model of cognition in order to: (1) understand creativity in the kitchen; (2) characterise culinary innovation processes; (3) establish whether some of these processes are general enough to be re-used in other fields and so broaden our theoretical understanding of the processes and mechanisms involved in creation and innovation. We present those features that are specific to gastronomy as a creative process to distinguish them from others that are generic enough to form part of a larger family of creative processes. The paper seeks to present new perspectives on both subject-specific and generic creation processes in haute cuisine.
\end{abstract}

Keywords: confection, avant-garde gastronomy, creativity models, Ferran Adrià.

Corresponding author: David Casacuberta. Departamento de Filosofía. Edificio B (Campus de la UAB) 08193 Bellaterra. Cerdanyola del Vallès (Spain).

Suggested citation: Casacuberta, D. (2021). Cognitive Models for Gastronomic Creation and Innovation. Debats. Journal on Culture, Power and Society, 6, 163-173. DOI: http://doi.org/10.28939/iam.debats-en.2021-11

\section{INTRODUCTION}

This article explores 'avant-garde gastronomy' from the perspective of enactivism in order to shed new light on innovation processes. The goal is to discover whether these processes can be generalised to other disciplines and thus advance our theoretical understanding of creativity and innovation mechanisms. Master Chef Ferran Adrià's creative gastronomy at el Bulli restaurant and his subsequent theoretical reflection in his el Bulli Lab research are analysed in this paper as a case study upon which our proposals are based.

In the first section, we describe the evolution of gastronomy and its study. The second section argues the theoretical relevance of gastronomy as an object of philosophical study. The third studies el Bulli from 
an enactivist perspective. The fourth and final section discusses how the ideas presented shed new light on innovation and creativity.

\section{A BRIEF HISTORY OF THE INTERDISCIPLINARY STUDY OF COOKING}

Gastronomy meets all the criteria for being an Applied Science. The kitchen is where a host of raw materials go through physical and chemical changes to yield the final product (Castells and Perelló 2010, McGee 1984, Myhrvold 2011). However, historically speaking, gastronomy and the Applied Sciences have shunned each other. In the past, cooking was based on previous experience, and recipes and techniques were the product of trial and error. There was no scientific review or comparison of cooking outcomes. Yet one can find centuries-old cooking techniques that tie in well with theoretical models in Chemistry and Physics, as well as age-old beliefs that do not stand up to scientific scrutiny (López-Alt 2015).

The first attempts to forge a 'Kitchen Science' were made in the 19th Century with researchers such as Appert - who described methods for preserving food (Appert 1810) - and Accum, a chemist interested in poisons and Forensic Sciences, author of the first treatise on chemistry in the kitchen (Accum 1821). A work of particular note was Savarin's The Physiology of Taste [Physiologie du goût ou Méditations de gastronomie transcendante] (Brillat-Savarin, 1828), which became the first discourse on scientific gastronomy. In his work, he tried to establish the physiological bases of our senses of taste and smell, and the chemistry of food processing.

In the twentieth century, the first author to passionately argue the case for a relationship between that science and gastronomy was the Hungarian Physicist Nicholas Kurti. He was a forerunner of the current trend of merging technology and gastronomy. Kurti gave his famous lecture "The Physicist in The Kitchen" in 1969 , in which he demonstrated the culinary scope of a vacuum machine and a microwave oven, among other things.
In the same year, Herbert Simon published his book The Sciences of the Artificial, which established Design as a science. Simon's theories sparked the quest for systematic methodologies covering many designrelated disciplines, such as Architecture, Engineering, Urban Planning, Medicine, Computer Science, and Management.

Following Dorst (2006) and Cross' (2007) ideas on design, one could say that gastronomy is a kind of 'design space' in which a chef has to solve poorlydefined problems to come up with a good solution. The difficulty is compounded by the fact that the problem itself is a constantly changing one and is framed within a complex feedback process. However, up until the turn of the 21st Century, there was no sustained attempt to analyse gastronomy from a Design Sciences angle.

In the 1980s, Harold McGee's (McGee 1984) encyclopaedia of food and cooking fostered dialogue between Science and the culinary art, building a paradigm from which it was possible to cook in a way that followed the scientific method. This gave scope for seeing cooking as a theoretical system based on sound scientific knowledge, to wit: molecular gastronomy, a term coined by Hervé and that was later taken up by Kurti (2002, Kurti 1980). Another key text is the Guia científica i gastronòmica [Scientific and Gastronomic Guide] (Fundació Alicia i el Bulli Workshop 2006), which drew up the first scientific classification of food products used in gastronomy.

However, these proposals tended to over-stress the Science, turning cooking into something akin to engineering and forgetting the 'creative' aspect of the craft - a problem alluded to above in Nigel Cross' comments.

Nathan Myhrvold tried to strike a balance between scientific and artistic creativity in these new culinary methods. He called the new trend 'modernist cooking' and wrote no fewer than six volumes on the subject in a systematic study of the effects of different techniques and technologies on food (Myhrvold 2011). However, 
he also strove to do justice to the creative and nondeterministic aspects of cooking. In Spain, Pau Arenós tried to strike a similar balance between art and science and in 1999 coined the term 'techno-emotional' cuisine (Arenós and Jardí 1999) to capture the blend of artistic inspiration and scientific method needed.

The two standard terms used to refer to this new paradigm - molecular gastronomy and techno-emotional cooking - have their strengths and weaknesses in shedding light on the nature of cooking. The term 'Molecular Gastronomy' reveals the scientific side to this discipline, pointing to chemistry as the key science. However, the term may mislead one into thinking that it only deals with finding new chemical reactions to come up with food textures. By contrast, the term 'Techno-emotional cooking' stresses the idea that gastronomy should not blind customers with science and jargon but rather surprise them with new emotions, letting them experience food in ways they could never have imagined. In speaking about his first time at El Bullí restaurant, Adrià said it came down to 'raping diners' palates' (Adrià 1998). The 'Techno' part of the term points to the need for new devices, techniques and technologies. However the term also leads the layman to think merely in terms of frivolous gadgets and 'tech' systems to present dishes in the strangest ways possible.

The Sensory Sciences are another important discipline when it comes to analysing gastronomy from the Design Sciences angle. The Psychology of Perception or Human Physiology is as relevant to gastronomy as it is to design (Korsmeyer 2002, Lyman 2012). Consider the concept of 'food-pairing'. Such research combines statistical analysis and Cognitive Science to draw up a methodology to discover which foods combine well and which do not, and seeks to go beyond traditional combinations. A clear example of this research is The Food-pairing Project (Robberechts et al., 2015), a food technology company at the forefront of Gastronomy, Computer Science and Digital Advertising. There is also the Barabasi-led project of establishing foodpairings by analysing common ingredients in recipes (Ahn et al., 2011).

\section{WHY ONE SHOULD RESEARCH GASTRONOMY. MYTHS AND REALITIES}

Gastronomy generally gets short shrift from the Sciences and Humanities. When examined from the standpoint of Aesthetics and other branches of Philosophy, the analysis is usually blatantly hostile. We only need to remember the insults that Plato dished up for cooks and peasants in The Republic. For Plato, food is a kind of necessary evil, and the less we talk about it the better.

This disdain is surprising since it is at odds with the daily routine of eating and cooking, and with the interest that gastronomy sparks in the general public. This ignorance and indifference is based on deeply-rooted prejudices.

\section{Aesthetics of the minor senses}

First, we have the idea that taste is a lesser sense that has no bearing on a study of the human condition. This prejudice sees taste as a primordial, animal sense that is too lowly to have the slightest epistemic or aesthetic relevance. The traditional taste categories - salty, sweet, bitter, sour and combinations thereof - do not allow the building of any conceptually relevant theoretical models.

Yet this vision is merely a self-fulfilling prophecy. It is the Platonic obsession with focusing on the pure world of thought and avoiding the body that causes us to lack detailed vocabulary to describe taste and explore its meaning.

Western culture lacks credibility when it comes to theorising on taste - something laid bare by the fact that we had to wait until the 20th Century to grasp the idea of unami - a new taste, associated with detecting proteins and substances such as monosodium glutamate. To draw a comparison with another sphere, it would be as if no art critic or vision theorist had ever spoken of violet until the twentieth century. We had to wait until 2010 to confirm something we already knew from experience, namely that fat is a flavour (Stewart et al., 2010, Keats and Constanzo 2015). We also had to wait until the 
21st Century for competent theories to emerge on how the sense of smell works - something that is a great deal more complex than just assuming that we have receptors in the nose for each type of molecule (Hawkes and Doty 2009).

\section{The economics of molecular cooking}

A more recent though lower hurdle to gastronomy being taken seriously by The Humanities is the characterisation of avant-garde cuisine as elitist and thus part of the wealthy classes' social capital. In other words, consuming Haute Cuisine is a sign that one belongs to the Upper Class. Being seen going into a Three-Star Michelin Guide restaurant, bragging about the experimental cuisine, and calling the chefs by their first names as if they were bosom pals is a form of social capital and show that one has money to burn on fripperies (Eloire 2018).

The main thrust of this argument is to stress the Social Capital aspect of such consumption and the eye-watering prices charged for such cuisine. The people dining at these avant-garde restaurants we are told - are paying through the nose for the ingredients, for getting on the waiting list, and for wallowing in the exclusiveness. The sky-high prices to dine at these places effectively bar the general public (Eloire 2018). Yet the accusation of price-gouging is largely unfounded. It is true that some restaurants and chefs take their customers for a ride, creating spuriously 'exclusive events' and including products of no gastronomic value (such as the use of gold leaf) in the kitchen a pretext for overcharging. Yet in general, the prices charged by avant-garde restaurants are not excessive (Sunday 2013, Christensen and Pedersen2011). The main reason for the high prices is the need for many highly-trained staff to serve a fairly small number of diners. In some restaurants, there are more people working in the kitchen than there are diners. In el Bulli's case, the restaurant actually ran at a loss. Where its Master Chef Ferran Adrià and his team really made their money was from associated events, conferences, workshops, and so forth (De Solier 2010, Sunday 2013). As Carme Ruscalleda said in an interview: "A tasting menu is not overpriced, whereas charging $€ 7$ for a toasted cheese-and-ham sandwich is daylight robbery" (Sarrias 2019).

As for the objection that avant-garde cuisine is nothing more than a way of showing off, one should note that the link between 'Social Capital' [conspicuous consumption] and aesthetic and cultural practices is no less exclusive than Haute Cuisine. Attending Art auctions, having one's own seat or box at an opera house, and buying artworks at a swish gallery are just a few examples of the same phenomenon. Yet this does not stop The Humanities from systematically studying the visual arts and opera. It is true that there is a hard core of Upper Class diners frequenting Michelin threestar restaurants to flaunt their social status. Yet there is now a growing number of ordinary customers who are genuinely interested in new gastronomic experiences rather than in Haute Cuisine as an exercise in one upmanship (Opazo, 2016). Similar market forces are at work at Bayreuth. There, the wealthy show up to show off. Meanwhile, a host of run-of-the-mill Wagner fans also turn up after having scrimped and saved for months to enjoy The Twilight of the Gods [Götterdämmerung], burning through their hard-earned cash. The link between avant-garde gastronomy and Social Capital must be studied but it should not be solely confined to this aspect.

A big part of Haute Cuisine's exclusiveness stems from the lack of mechanisms for reproducing the experience. Until the advent of sound reproduction technologies in the 20th Century, enjoying classical music was clearly a minority experience. We must also distinguish between 'elitist' and 'minority' consumption patterns. The dodecaphonic music of Schönberg and Alban Berg leaves most people cold. One needs a well-developed knowledge of music theory to enjoy it (and even then, it is not everyone's cup of tea). Yet we would not say that it is elitist music but rather music for minorities. (Vilar 2018).

Finally, one of the reasons why avant-garde restaurants are now in the limelight is because gastronomy has largely been ignored in the past. It is only now that The Humanities are beginning to properly study 
gastronomy and recognise its worth (Vilar 2018) (Vilar and Jaques 2010) in a way reminiscent of the attention lavished on the visual arts. Yet one does not need to venture into an avant-garde kitchen to study gastronomy as a creative act.

\section{ENACTIVIST ANALYSIS OF CREATIVE PROCESSES IN MOLECULAR GASTRONOMY}

This section is the result of my participation in the Sapiens project (originally called Decoding) in el Bulli Lab and the description of the results of the methodology in Adrià and Pinto (2015). I therefore describe the projects at the time without delving into further results of the Sapiens project. Those wishing to delve deeper can consult the following interactive presentation produced by Ferran Adrià and Ara newspaper: https:// interactius.ara.cat/sapiens/en [English version]

One of my tasks in this project was to establish cognitive enactivist models that could shed light on the creative processes in molecular gastronomy. In this paper I review how such models provide a better understanding of the creative processes at el Bulli and how they might be transferred to other settings.

\section{What is an enactivist cognitive model?}

By enactivism we mean a way of understanding the Cognitive Sciences other than through computational or representational models, and that sees cognition as a dynamic process in which subject, body and setting continuously interact to create cognitive models that we cannot simply place in the brain but that are also the result of this continuous interaction between mind, body and environment (Thompson 2010, Noë 2015).

An enactivist cognitive model thus functions as an extended mind system where the cognitive process solves a problem in a way that does not merely stem from brain computation but also from a process of analysis that extends to the environment.

Hutchins (1995) gives a simple example of this idea: Imagine a queue of customers at a bakery waiting to be served. Those in the queue are told roughly how long they can expect to wait before reaching the front. This lets each customer decide whether he wants to stay in the queue or leave. The place in the queue establishes the order in which customers will be served (assuming they do not lose patience and leave). The cognitive process does not stem just from the baker's mind or from customers' reckoning of the time to reach the front but rather from the interaction of all minds, customers' bodies, and a given spatial form (to wit, a queue).

Enactivist cognitive models are very recent. Enactivism - or the third generation of the Cognitive Sciences - began with the publication of The Embodied Mind in 1991 yet it has only recently taken root in The Humanities.

This fact is key to grasping the lack of interest in gastronomy discussed earlier. A classical cognitive perspective focusing on a brain that knows when the context is irrelevant finds it very hard to understand cooking, which is a highly context-dependent activity involving interaction between individuals.

Taking a Cartesian approach makes it very hard to grasp how gastronomy really works at the phenomenological level. Historically, the idea was to start from the brain as a taste-processing machine and thus reduce gastronomic pleasure to a set of computations.

However, there is no need to reduce the phenomenological experience of gastronomy to the sense of taste. Clearly taste sensations may arise when we ingest something, for example orange juice. Yet these cannot be limited to a combination of sweet, salty, bitter, sour and umami otherwise one could create any possible flavour by blending these five tastes - a proposition that is clearly absurd.

This though is precisely the reductionist approach taken by the neuroscience of taste. Take the famous study by Morrot et al., (2001) where some sommeliers were tricked into believing they were tasting a 'red 
wine'. What they had actually been given was a white wine reddened with a dye. Many commentators saw this experiment as evidencing 'socialisation' of gastronomy and as proof that the supposed wine experts knew nothing. Yet the issue here was not the experts' knowledge given that sommeliers are not mere molecule detectors but rather human beings with multi-sensory skills. Accordingly, they make holistic judgments based on taste, aroma, appearance and so forth. The same phenomenon would explain why people say that a more expensive wine tastes better than a cheaper one. This occurs even when they are tasting exactly the same wine, albeit one poured from differently-labelled bottles.

From an enactivist standpoint, we can grasp the confusion that surrounds words describing taste and how it relates to chemical receptors on the tongue (Noë 2015). Yet taste is actually a multisensory experience that includes the sense of smell and touch. Here one should note that spicy or astringent flavours arise from the tongue's sense of touch, not its chemical receptors. One also needs to include sight (this sense actually plays a basic role in any taste experience). Hearing is a less important sense but comes into play in gauging how crunchy a food is.

Thus tasting involves a combination of taste, smell, touch, and is not confined to food's interaction with the tongue's chemical, receptors.

It is also worth noting that although we are well

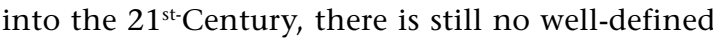
vocabulary to describe aromas and tactile sensations. Thus there is no comprehensive list of aroma types. Researchers are currently working with classification schemes that are drawn from the world of perfumery but that are neither consistent nor systematic.

Ferran Adrià is a chef who has radically changed gastronomy over the last half century. His research is always driven by a desire to innovate. During Adrià's time running his el Bulli restaurant along with his creative team, the focus was always on "a return to creation" (Adrià 2015). Work at the restaurant was always organised on a sound scientific footing. Research lab principles and purpose were adopted, rigorously drawing on observation, experimentation, research, making hypotheses, creating models and techniques. These were the basic ingredients for reviewing and questioning gastronomy as a discipline in order to drive constant change and improvement. Today, any internationally recognised chef will readily acknowledge his debt to Ferran Adrià. (Opazo 2012, 2016).

We should not see molecular gastronomy, and especially the el Bulli project, as a kind of objectification and scientification of the kitchen in which inspiration and intuition are banished something apparent in the standard reviews of the molecular gastronomy project (see Cousins et al., 2010, Hegarty and Antun 2010). Rather, gastronomy involves being just as creative as other forms of cooking. Resort to science and technology does not render gastronomy a mechanical process but rather facilitates creation and innovation.

Once el Bulli closed, Ferran Adrià decided to conduct systematic research on creativity itself with a view to finding a method that would facilitate innovation and creation in any discipline. The project was originally titled Decoding and sought to formally reconstruct the creative processes and mechanisms of various disciplines but with a clear stress on cooking. Nevertheless, the idea was to look at other disciplines to pin down which parameters were universal and which only applied to a given discipline. The idea was to 'decode' various strands such as: (1) recipe creation; (2) restaurant interior decoration; (3) cocktails; (4) contemporary dance; (5) business administration. Later on, the el Bulli Lab team changed the project name to Sapiens but the goal was the same - namely to come up with a kind of logical reconstruction of the world [Der logische Aufbau der Welt] (Carnap 1928) albeit one confined to creative processes.

The project began with Ferran Adrià's findings from analysing his own creative path. Right from the outset at el Bulli, Adrià and his team analysed the 
various creative processes and structures, examining menus, product sheets, preliminary ideas for new dishes, the database of tests, recipes that did not work, and so on. The way el Bulli's team works is easily understood from an enactivist perspective. One of these findings runs counter to the romantic notion of the creative genius who basically invents whatever he chooses. The reason the notion is false is because culinary creativity is heavily conditioned by the physical, chemical and organoleptic properties of foodstuffs, the technologies of the day, and time and staff constraints.

This rigorous approach lets Adrià establish some basic parameters for developing his 'decoding process'. Regardless of whether one is trying to innovate in cooking, video art or the design of racing cars, there are a number of generic conditions that can help or hinder the creative process. However, these self-same constraints make creativity possible in the first place. That is because without constraints, one could conjure up any texture and flavour from any ingredients at will. Under such a scenario, coming up with the desired dish would be as routine and unremarkable as churning out widgets. The fact that things do not work like this in the real world is what creates the need for Master Chefs capable of harnessing their experience to find new ways to innovate.

It follows from the Sapiens project and the research patterns of the enactivist model that creative processes in cooking are distributed thus there is no ultimate creative genius responsible for the dish - a fiction assiduously promoted by the popular press. Instead, dishes are a team effort by chefs, 'sandwich students' (no pun intended), producers, distributors, and diners. On the other hand, no creative process takes place in a vacuum (not even cooking) so we must include other disciplines that may inspire the creative process on the one hand, and historical and environmental conditions on the other.

Let us look at the historical conditioning factors first. Behind the aforementioned food-pairing, the fact that certain food combinations work in the kitchen while others do not is the result of a historical process. It would be a mistake to think that food-pairing is something that is part of our brain circuitry. Rather, it is the product of an enactivist process in which mind, body, and environment work together.

The culinary canon stems from the adoption of certain recipes as a standard, the result of a combination of sundry climatic, technological, social and even religious factors. If we believe that onions, aubergines, peppers and tomatoes are a good combination, it is not simply because of their molecular compatibility but because of centuries of history that have kept them together. The new label for Adrià's project (Sapiens) is a tribute to Harari's book of the same name (Harari 2014) and thus recognises the great role played by history in the creative processes of gastronomy.

The creative processes in Avant-garde cuisine have a strong interdisciplinary component. The Roca Brothers 'Roner or Rotoval [basically a distilling apparatus for food aromas] is the result of applying Physics and Chemistry principles to the kitchen. The inclusion of Ferran Adrià in the Documenta Art Biennial (Todolí and Hamilton 2009) is explained by the Master Chef's tributes to the visual culture of the 20th Century with dishes such as Molls Gaudí [Mullet à la Gaudí] (Adrià 1998).

Another key feature of the Sapiens model is that it gives the chef more time to be creative. This is why Adrià chose to keep el Bulli closed for six months and to serve only dinners, giving the el Bulli team enough time to do new tests and experiments, seek inspiration elsewhere, travel to find new techniques, ideas and products, and so forth. Restaurant logistics are also key to linking each stage of the maintenance programme, ensuring a smooth, trouble-free flow. The schedule kept the restaurant open without cognitively over-burdening the team, giving it as much time as possible to spend on culinary creativity.

Probably the most important element of the Sapiens methodology is that it maximises efficiency of 
productive and creative processes, subjecting these to rigorous analysis, examining them in depth and ensuring that they all 'gel' (Maes 1994). A key result of these micro studies is that each discipline has its own creative mechanisms that cannot automatically be applied to another discipline. A detailed reworking is needed, reconstructing the specific connections between the objects, products and methods in each case. For instance, although one might posit that the creative mechanisms in graphic design and cooking are similar (insofar as they both deal with the suitability of certain combinations), this is insufficient. If we really wish to grasp the relationship between 'food-pairing' and 'colour-pairing' we need to analyse and systematise the mechanisms at work in each case and their respective psychological and historical bases. Deeper consideration reveals that whether two flavours or two colours combine well or not are independent processes notwithstanding their superficial similarities.

The Sapiens analysis also shows that limitations do not hinder creativity but on the contrary spur it. Creativity is Mankind's response to certain constraints imposed on it by historical and environmental forces. It is only by grasping these limitations that we can come up with truly creative answers. This ties in with Cross' scheme for visualising seemingly intractable problems and then deciding how far one is willing to go in questioning the limitations they seemingly pose. In classic cuisine repertoires, it is very hard to find dishes that are completely black. Is this non-existence the result of something intrinsic in the nature of these foods? Is it a cross-cultural psychological fact or is it the result of historical and social processes? Once we understand this phenomenon we can consider whether it makes sense to make a dish where all the ingredients are black and, if so, how it should be produced. This decision in turn spawns new problems: Should the dish be served on a black plate?; When should the menu be served?; Are other sensory accompaniments needed?

Sundry enactivist cognitive processes will be involved, which are briefly listed in the table below, which compares traditional and molecular cuisines:

Table 1

\begin{tabular}{|l|l|l|}
\hline \multicolumn{1}{|c|}{ Problem } & \multicolumn{1}{|c|}{ Traditional Cuisine model } & \multicolumn{1}{c|}{ Molecular Gastronomy model } \\
\hline Record recipe & $\begin{array}{l}\text { Ambiguous text based on } \\
\text { shared experience }\end{array}$ & Scientific writing of a recipe, exact quantities, etc. \\
\hline $\begin{array}{l}\text { Decide on the right } \\
\text { combinations }\end{array}$ & $\begin{array}{l}\text { Intuitive knowledge based on } \\
\text { shared tradition }\end{array}$ & $\begin{array}{l}\text { Systematic historical and biological knowledge } \\
\text { that explains these intuitions }\end{array}$ \\
\hline $\begin{array}{l}\text { Innovate in } \\
\text { techniques }\end{array}$ & $\begin{array}{l}\text { Intuitive use of new utensils } \\
\text { (pressure cooker, microwa- } \\
\text { ve, etc.) }\end{array}$ & $\begin{array}{l}\text { Use based on simple science and the capabilities } \\
\text { of new utensils }\end{array}$ \\
\hline $\begin{array}{l}\text { Innovating in } \\
\text { technologies }\end{array}$ & Trial and error & $\begin{array}{l}\text { Ask engineers to use their scientific knowledge to } \\
\text { come up with new technologies (rotaval, roner) }\end{array}$ \\
\hline $\begin{array}{l}\text { Innovate in } \\
\text { combinations }\end{array}$ & Trial and error & $\begin{array}{l}\text { Combine chemical, neurological and historical } \\
\text { knowledge. (Food-pairing) }\end{array}$ \\
\hline
\end{tabular}




\section{CONCLUSIONS}

Although at first glance there seems to be a big gap between traditional cuisine and 'molecular gastronomy', in reality the latter is nothing more than an attempt to systematise cooking by drawing on the experimental sciences, cognitive models, chefs' hunches.

Understanding gastronomy therefore requires an enactivist perspective in which mind, body and environment interact through endless feedback loops. Gastronomy is also a multi-sensorial system in which the expectations and knowledge of diners and chefs play a key role. El Bulli Lab's Sapiens project is a perfect example of this kind of research, which starts from the kitchen setting to pin down generic mechanisms that can be transferred to other disciplines.

One of the key findings to emerge from this methodology is that limitations spur creativity as we try to overcome them. Kant's dove hopes to fly better in an airless space but discovers this supposed constraint (air) is a precondition for flight. Likewise, the limitations imposed on us by each discipline are what lets creativity take wing.

These limitations differ in each discipline both in terms of the factors inherent in production processes and in what has historically been seen as an acceptable outcome and which has not.

That is why a study of creativity cannot hope to find generic mechanisms that will work in any setting. Put another way, we cannot mechanise creativity as a generic process or expect to find a global formal model governing it. What we can do is systematically identify which mechanisms either help or hinder creativity by earmarking more time to the creative process and by lightening the cognitive burden stemming from other activities.

We can think of Sapiens as a Wittgensteinian exercise revealing that 'creativity' is a term loosely bandied around in many settings. This is why it is pointless to seek universal laws spanning all disciplines. Instead of trying to draw up universal, immutable laws governing creativity, we should look for generic protocols that help people spend more time and thought on the creative process.

At the same time, Sapiens shows that creativity stems not from a genius inspired by The Muses but from a team effort in which creation is a collective, distributed affair (Hutchins 1995). Here creativity arises from a tightly-co-ordinated team, working with sundry technological tools, and shaped by environmental and cultural factors.

\section{BIBLIOGRAPHIC REFERENCES}

Accum, F. C. (1821). Culinary Chemistry, Exhibiting the Scientific Principles of Cookery. London: R. Ackermann. Adrià, F. (1998). Los Secretos de el Bulli: recetas, técnicas y reflexiones. Altaya.

Adrià, F. and Pinto. J. M. (2015) "Sapiens: Una metodología para entender la gastronomía". ELISAVA Temes de Disseny, Issue 31, Barcelona: Elisava, pp. 10-21.

Ahn, Y. Y. and Ahnert, S. E., Bagrow, J. P., and Barabási, A. L. (2011). "Flavor network and the principles of food pairing". Nature Scientific reports, Issue 1.

Appert, N. (1810). L'art de conserver pendant plusieurs années toutes les substances animales et végétales. Paris: Chez Patris.

Arenós, P.; Jardí, E. (1999). Los genios del fuego: quiénes son, cómo crean y qué cocinan 10 chefs de vanguardia. Barcelona: Ediciones Península. 
Brillat-Savarin, J.A. (1828). The Physiology of Taste, or, Meditations on Transcendental Gastronomy. Translator M. F. K. Fisher. Washington, DC: Counterpoint Press.

Carnap, R. (1928). Der logische Aufbau der Welt. Berlin: Schlachtensee. Celant G. (2015). Arts and Design. Rituals since 1851. Milan: Electa.

Celant G. (2015). Arts and Design. Rituals since 1851. Milan: Electa.

Castells, P. and Perelló, J. (2010). "Materia Condensada. Cocinar Ciencia” in Cocinar ciencia. Materia condensada. Barcelona: Actar.

Christensen, B. T., and Pedersen, J. S. (2011). Evaluative Practices in the Culinary Field - A Case of Restaurant Rankings. Copenhagen Business School, 2-20.

Cousins, J., O'Gorman, K., and Stierand, M. (2010). Molecular gastronomy: cuisine innovation or modern day alchemy? International Journal of Contemporary Hospitality Management.

Cross, N. (2007). Creativity: Flow and the Psychology of Discovery and Invention. New York: Harper \& Collins.

De Solier, I. (2010). Liquid nitrogen pistachios: Molecular gastronomy, el Bulli and foodies. European Journal of Cultural Studies, 13(2), 155-170.

Domene, M. (2013). El Bulli: Contemporary Intersections between Food, Science, Art and Late Capitalism. Barcelona Investigación Arte Creación, 1(1), 100-126.

Dorst K. (2006). "Design Problems and Design Paradoxes". Design Issues, vol. 22, Issue 3 (Summer), pp. 4-12.

Editorial, T. C. (2017). Terminàlia parla amb... Carme Ruscalleda i Serra, primera xef catalana que aconsegueix set estrelles Michelin. Terminàlia, 38-41.

Eloire, F. (2018). The Bourdieusian conception of social capital: a methodological reflection and application. In Forum for Social Economics (Vol. 47, No. 3-4, pp. 322-341). Routledge.

Fundación Alicia and el Bulli Taller (2006). Léxico científico gastronómico. Barcelona: Planeta.

Harari, Y. N. (2014). Sapiens. De animales a dioses: Una breve historia de la humanidad. Debate.

Hawkes, C. H., and Doty, R. L. (2009). The neurology of olfaction. Cambridge University Press.

Hegarty, J., and Antun, J. (2010). Is the Chemical Chef Dividing Culinary Arts and Gastronomy? Journal of Culinary Science and Technology. Volume 8. Issue 2-3 pp. 73-82.

Hutchins, E. (1995). Cognition in the Wild (No. 1995). MIT Press.

Keast, R. S., and Costanzo, A. (2015). Is fat the sixth taste primary? Evidence and implications. Flavour, 4(1), 5.

Korsmeyer, C. (2002). Making sense of taste: Food and philosophy. Cornell University Press.

Kurti, N. (1980). "The physicist in the kitchen." New Scientist Issue 88, pp. 786-9.

López-Alt, J. K. (2015) The Food Lab: Better Home Cooking Through Science. W. W. Norton \& Company.

Lyman, B. (2012). A Psychology of Food: More than a matter of taste. Springer Science \& Business Media.

Maes, P. (1994). "Agents that reduce work and information overload". 2 Communications of the ACM, 37(7), pp. 30-40.

McGee, H. (1984). On food and cooking: the science and lore of the kitchen. New York: Simon and Schuster.

Morrot, Brochet and Dubourdieu G. (2001) The Color of Odors. Brain and Language.

Myhrvold, N. (2011). Modernist Cuisine. Cologne, Germany: Taschen.

Noë, A. (2015). Strange Tools: Art and human nature. Hill and Wang.

Opazo, M. P. (2012). Discourse as driver of innovation in contemporary haute cuisine: The case of el Bulli restaurant. International Journal of Gastronomy and Food Science, 1(2), 82-89.

- (2016). Appetite for Innovation: Creativity and change at el Bulli. Columbia University Press.

Plato. La República A: Diàlegs, vol. X. Introduction and translation by Manuel Balasch. Barcelona: Fundació Bernat Metge, 1989.

Robberechts, D., Lahousse, B., Coucquyt, P., and Langenbick, J. (2015). U.S. Patent Application No. 14/165,455.

Sarrias, T. (2019) Punt de Vista. Entrevista a Carme Ruscalleda. RTVE. https://www.rtve.es/alacarta/videos/puntsde-vista/punts-vista-entrevista-carme-ruscalleda/5480837/ (last accessed 11/08/2020)

Simon, H. A. (1996). The Sciences of the Artificial (Vol. 136). Cambridge: MIT Press. 
Stewart, J. E., Feinle-Bisset, C., Golding, M., Delahunty, C., Clifton, P. M., and Keast, R. S. (2010). Oral sensitivity to fatty acids, food consumption and BMI in human subjects. British Journal of Nutrition, 104(1), $145-152$.

This, H. (1999). "Nicholas Kurti, one of the founding fathers of molecular gastronomy". Acta Physica Hungarica New Series-Heavy Ion Physics, 10(1), 21-28.

This, H. (2002). Casseroles et éprouvettes. Paris: Berlin pour la science.

Thompson, E. (2010). Mind in life. Harvard University Press.

Todolí, Vicente; Hamilton, Richard (editor) (2009). Menjar per pensar, pensar per menjar. Barcelona: Actar.

Vilar, G . (2018). La cognificació de l'art. Quaderns de filosofia, 5(2), 11-28.

Vilar, G. and Jacques, J. (2010) “Feeding thought: por una filosofía de la gastronomía y la cocina" Disturbis. Autumn [on line]. Retrieved from www.disturbis.esteticauab.org/DisturbisII/Indice_12.html (last accessed 11/04/2019).

\section{BIOGRAPHICAL NOTE}

\section{David Casacuberta}

He was awarded a PhD by the Autonomous University of Barcelona (UAB). He is currently a Lecturer at the same university. His research lines cover the social and cognitive impacts of digital technologies, especially in relation to ethical and epistemological issues that arise from the application of said technologies in the Biomedical Sciences. 


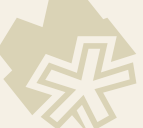

